\title{
Intertidal rocky shore biotopes of the Azores: a quantitative approach
}

Received: 10 August 2005/ Revised: 13 January 2006/ Accepted: 13 January 2006/Published online: 3 February 2006 (C) Springer-Verlag and AWI 2006

\begin{abstract}
Rocky littoral communities of the Azores are dominated by macroalgae where turf formations represent the main life form as on many subtropical and tropical shores. The present study aimed at describing and classifying benthic intertidal biotopes of the Azores using clear quantification and data analysis methodologies to be used in similar studies for spatial and/or temporal comparison. This numerical approach intends to have management and conservation applicability. Thirty study locations along the coast of São Miguel island were characterised by substratum type (cobbles, boulders or bedrock - different stability levels) and exposure to wave action (high, medium or low exposure), from June to August 2002. Algae, sessile and sedentary invertebrates were recorded along transects, and the more conspicuous taxa quantified. Community structure is mainly shaped by substratum stability unstable cobble communities are separate from those of more stable boulders and bedrock. Boulders present an intermediate community composition between cobbles and bedrock. Exposure to wave action induces smaller variation in community composition. Sixteen biotopes have been recognised. Ultimately the present paper provides an objective set of biotope definition tools for a broad public whose interest focuses on spatial and temporal comparison of coastal communities and associated habitats.
\end{abstract}

Keywords Rocky shores - Community structure · Biotopes $\cdot$ Methodologies $\cdot$ Comparative studies

Communicated by H.-D. Franke

F. F. M. M. Wallenstein $(\bowtie) \cdot$ A. I. Neto

Secção de Biologia Marinha, Laboratòrio de Ficologia,

CIRN and Departamento de Biologia da Universidade dos Açores,

Apartado 1422, 9501-801 Ponta Delgada, São Miguel - Açores

E-mail: fmacedo@notes.uac.pt

Tel.: + 351296650000

Fax: +351296650100

\section{Introduction}

The archipelago of the Azores is located roughly between coordinates $37^{\circ}$ to $40^{\circ} \mathrm{N}$ and $25^{\circ}$ to $31^{\circ} \mathrm{W}$. It includes nine volcanic islands and several small islets. All the islands are formed by volcanic rocks (mainly basalt) and surrounded by deep water (a depth of $1000 \mathrm{~m}$ may occur within 2 or $3 \mathrm{~km}$ off shore). The coastline is extremely rugged owing to its recent volcanic formation. In many places the coast consists of high and steep cliffs while in others the shoreline is composed of large irregular rock masses. The more vesicular rocks provide a large number of irregular crevices of different sizes which harbour a considerable fauna and which provide a good substratum for the attachment of algae. The less vesicular types are more dependent on the algal growth for the retention of its fauna. Certain shores consist of a layer of rounded boulders between which coarse sand or gravel may be retained. Sandy shores are few in number. Most shores are exposed to strong swell. Few shores are sheltered, except for some bays and harbours. Tides are semi-diurnal and tidal range is less than $2 \mathrm{~m}$, even at extreme neap tides. For São Miguel island, the maximum tidal difference recorded was $1.89 \mathrm{~m}$, the mean values being $0.65 \mathrm{~m}$ in neap tides and $1.44 \mathrm{~m}$ in the spring tides (Instituto Hidrográfico 1981). Even during summer, long swells generated far away frequently reach the islands and break upon the shore. Extremely heavy seas occur during winter. Monthly mean values of air temperature show a regular annual variation with a maximum $\left(22 / 23^{\circ} \mathrm{C}\right)$ in summer and a minimum $\left(13 / 14^{\circ} \mathrm{C}\right)$ in February/March (Ricardo et al. 1977; Instituto Hidrográfico 1981). The coastline of São Miguel, mainly of high, steep cliffs with a variety of stacks, arches and gully formations, is about $155 \mathrm{~km}$ in length. Seashores are generally steeply sloping and mostly of difficult access by land. In some places there are attractive bays with cobblestones and bedrock where depths of less than $30 \mathrm{~m}$ extend several hundred metres offshore (Brito 1955).

The intertidal communities of the Azores have been studied for the past 70 years, with several papers 
published on the prevailing zonation patterns (see Neto 2000a, 2000b). Only recently research has been developed on the structure of those communities (Neto 1991, 1992, 2000a, 2000b), but no detailed study was done concerning their ecology and relationship to environmental abiotic variables. However, these type of studies on coastal and shallow water community structure and diversity at differing spatial and temporal scales have been done elsewhere (e.g. Southward and Orton 1954; Russell 1991; Zacharias et al. 1999; Foster et al. 2003). These have focused recently on the identification and characterisation of recurring communities and their relationship to environmental and abiotic variables (Zacharias and Roff 2001). Many have been the studies on benthic communities that have classified assemblages as biocenoses (Augier 1982; Dauvin et al. 1994; Dauvin 1995), biotopes (Hiscock 1995; Connor et al. 1997, 2003; Picton and Costello 1997; Tittley et al. 1998; Zacharias et al. 1999; Tittley and Neto 2000), facies (Pérès and Picard 1964) and zoogeographical units (Cerame-Vivas and Gray 1966). Habitat and community characterisation for marine conservation purposes has been the latest trend (Mumby and Harborne 1999; Zacharias and Roff 2000). One of the most comprehensive studies on community classification is the marine biotope classification developed for Great Britain and Ireland by Connor et al. (1997, 2003, recently republished as website http:// www.jncc.gov.uk/marine/biotopes/default.htm). Here, as accepted in the present study, biotopes are defined as assemblages of species associated to the habitat characteristics at which they occur, and names are given to these associations. Connor et al. (1997, 2003) aims at establishing a set of rules for naming communities and hierarchies of terminology, as are the cases of the phytocoenological approaches to coastal community ecology of Braun-Blanquet (1928) for plant communities, and of den Hartog (1959) and den Hartog and Segal (1964) for water plant communities. Although interesting and useful, these works do not provide clear methods for obtaining and/or analysing quantitative data, thus lacking applicability for spatial and temporal comparative purposes. Additionally these classifications were developed for temperate shores where canopy forming and foliose seaweeds are the visually obvious and characterising components of the biota. This situation is quite distinct from the one occurring on Azorean shores where large fucaceans are absent from the intertidal, and foliose and frondose algae are present only at the lowest level (Neto 2000, 2001). The eulittoral is dominated by turfforming algae communities, usually less then $3 \mathrm{~cm}$ in height, which cover the rocks as a compact mat. These turf communities were found to be the major structuring feature of intertidal Azorean shores (Neto 2000a, 2000b). Turf is frequently dominated by coralline algae directly attached to the rocks (Chapman 1955; Larkum 1960; Pryor 1967; Neto 1991, 1992; Neto and Tittley 1995; Tittley et al. 1998). These communities are physiognomically identical to those described elsewhere. The examples of the Atlantic Ocean are those of Cape Verde
Islands (Otero-Schmitt 1993), the Canary Islands (Lawson and Norton 1971), West Africa (Lawson and John 1982), the Caribbean (Rogers and Salesky 1981) and Brazil (Oliveira and Mayral 1976); for the Pacific Ocean, California and Mexico (Stewart 1982, 1989), Chile (Santelices and Abbot 1978) and Australia (the Great Barrier Reef, Price and Scott 1992).

The provisional benthic biotope classification for Azorean rocky shores outlined by Tittley et al. (1998) and Tittley and Neto (2000), following the lines of Hiscock (1995) and Connor et al. (1997), was merely qualitative and focused only on stable rocky substrata (not considering mobile cobbles). It was based solely on descriptive information and on a subjective classification of wave-exposure. Here the authors identified structural differences between Britain and Azorean intertidal communities and established two broad types of turf biotope complexes. However, no detailed information was provided on their ecology and zonation.

The present study aims to review and expand the Azorean biotope classification of Tittley and Neto (2000) defining accurate coastal ecosystem classification methodologies for management purposes. Instead of limiting biotope classification to naming associations of assemblages and habitats, special attention is given to spatial and temporal comparability of results with the intention to widen its applicability to coastal management. The generalised use of clearly defined methodologies is the only way to assure comparability. The island of São Miguel was used as a case study for a quantitative approach, which broadens the spectrum of substrates used for algal-characterised biotope classification. Ultimately, it aims at providing clear methodologies to be used in further biotope surveys in the Azores and elsewhere with spatial and temporal comparative purposes.

\section{Materials and methods}

\section{Location selection}

A total of 30 sampling sites distributed around the entire coast of São Miguel island were randomly selected from a subset of 70 suitable sites for detailed biotope study. At each site physical features were classified and recorded as follows: (1) substratum type - bedrock, boulders or cobbles, according to Leeder (1982); (2) degree of exposure to wave action - medium or high, as in Macedo (2002); and (3) slope of the coast - low, medium low, medium high or high, as in Macedo (2002) (Fig. 1). Exposure to wave action was calculated for the island of São Miguel in Macedo (2002), according to the physical model of Thomas (1986) based on fetch, wind speed and direction. Macedo (2002) used basic trigonometry to calculate shore slope, assuming it to be constant from the highest point of the transect line to low-water level. 


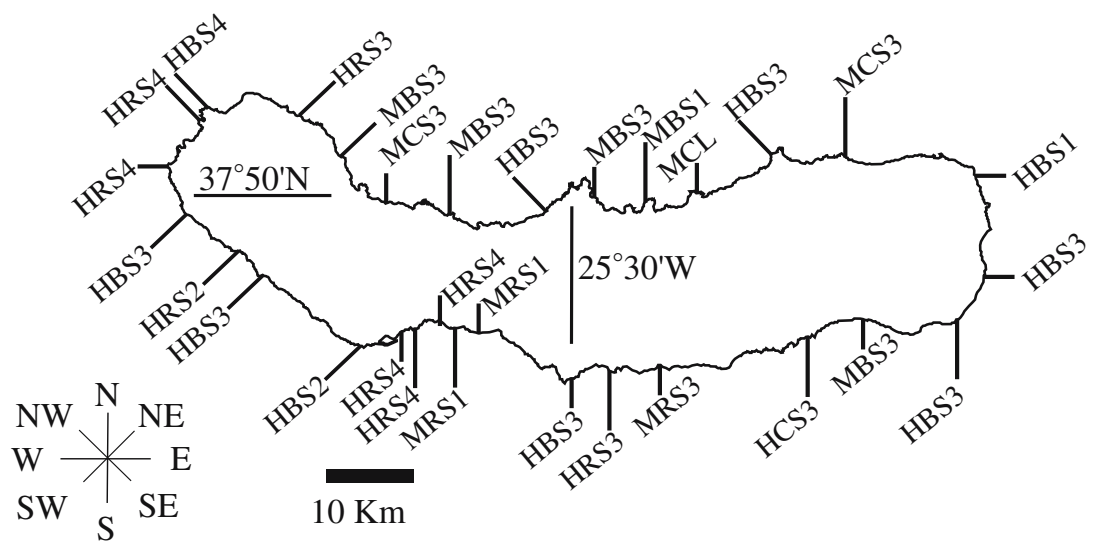

Fig. 1 Sampling sites on São Miguel island (Azores) (locations are labeled by three capital letters and a number. The first letter refers to exposure to wave action: $H$ - high; $M$ - medium. The second letter refers to substratum: $B$ - boulders; $C$ - cobbles; $R$ - bedrock.
The last letter followed by a number refers to slope: $S 1$ - high; $S 2$ medium high; $S 3$ - medium low; $S 4$ - low. Lines by each sampling site indicate the geographical direction that the site is facing)

\section{Sampling}

To identify recurrent patterns of algae assemblages across sampling sites, a stratified random sampling method was used that involved quantitative recording of taxa along a transect line laid perpendicularly to the coastline across the intertidal area, from the point at which an alga was first observed, and extending to low water level. Alternation between cobble bays and boulder/bedrock headlands is the common distribution of substrata along the coast of São Miguel island and these tend not to be mixed. However, it is possible to find sites where boulders and bedrock are mixed, and at the transition from cobble bays to boulder/bedrock headlands it is also possible to find mixed substrata. These situations were avoided to restrict sampling to a single substratum type at each site, where only one transect was sampled. Sampling across the 30 selected sites took place during the summer period, randomly between June and August 2002. Frequency of occurrence of each algal taxa present in quadrats was taken at three shore levels: (1) where the first alga was recorded (=upper littoral), (2) half-way between the first alga and low-water level (=mid-littoral), and (3) at lowwater level (=lower littoral). Barnacles (Chthamalus stellatus) and limpets (Patella spp.) were also counted when present. Elevations along transects were determined relative to an intertidal benchmark of known elevation, following the spirit-leveling method (Hawkins and Jones 1992). All elevations were related to Chart Datum, Azores (CD), by using the level of the sea at the time of prediction of low-water level. Considering the presence of residual swell even on calm days and the simplicity of the method used, the elevations are approximate $( \pm 0.1 \mathrm{~m})$.

Five replicate quadrats at each shore level were placed at right angles to the transect line in a direction and distance was determined by double-digit random values. The first digit indicates which direction to place the quadrat (pair numbers - to the left of the transect line when facing the sea; odd numbers - to the right of the transect line when facing the sea), and the second digit indicates the distance in metres $(\mathrm{m})$ relative to the precedent quadrat reading (minimum $1 \mathrm{~m}$ and maximum $9 \mathrm{~m}$ distance). For all substratum types, quadrats were placed at the upper- or sea-facing sides of the rocky surface. Frequency recording of taxa was done by a point-to-point method in $0.25 \times 0.25 \mathrm{~m}$ quadrats with 36 intersection points (Hawkins et al. 1990; Neto 2000a, 2000b). The number of intersection points at which a species/taxa occurred was counted. If possible, all taxa coinciding with intersections were identified to species level in situ. If not, the non-identifiable specimens were given a code name, taken to the laboratory to be identified to species level. Turf constituents were frequently difficult to identify, especially in the case of multispecific turfs. To cope with this fact different kinds of turf were given a general code name - turf - and their classification as thin, thick or calcareous turf was done in the laboratory according to the DAFOR quantification of their constituents.

\section{Data analysis}

Each species/ taxa frequency (numbers recorded) was converted into percentage cover by dividing it by the total number of intersections (36) in each quadrat for quantitative analysis. The analytical methods used PRIMER (Clarke and Warwick 2001), and consisted of a sequence of nmMDS (non-metric multidimensional scaling), MVDISP (multivariate dispersion), ANOSIM tests (non-parametric procedure applied to the rank similarity matrix underlying the ordination of quadrats) and SIMPER analysis (species contribution to similarity) were applied to the square-root transformed data. 
Table 1 List of taxa and corresponding authorities

\begin{tabular}{|c|c|}
\hline Taxa & Authorities \\
\hline \multicolumn{2}{|l|}{ Clorophyta } \\
\hline Chaetomorpha aerea & (Dillwyn) Kützing \\
\hline Chaetomorpha pachynema & (Montagne) Kützing \\
\hline Cladophora prolifera & (Roth) Kützing \\
\hline \multicolumn{2}{|l|}{ Cladophora sp. } \\
\hline Cladophoropsis membranacea & (C. Agardh) Borgesen \\
\hline Codium adhaerens & C. Agardh \\
\hline $\begin{array}{l}\text { Codium fragile subsp. } \\
\text { tomentosoides }\end{array}$ & (van Goor) P.C. Silva \\
\hline $\begin{array}{l}\text { Ulva (Enteromorpha) } \\
\text { compressa }\end{array}$ & (Linnaeus) Greville \\
\hline $\begin{array}{l}\text { Ulva (Enteromorpha) } \\
\text { intestinalis }\end{array}$ & (Linnaeus) Link \\
\hline Ulva rigida & C. Agardh \\
\hline \multicolumn{2}{|l|}{ Phaeophyta } \\
\hline Cladostephus spongiosus & (Hudson) C. Agardh \\
\hline Colpomenia sinuosa & (Roth) Derbès et Solier \\
\hline Cystoseira abies-marina & (S.G. Gmelin) C. Agardh \\
\hline \multicolumn{2}{|l|}{ Dictyota sp. } \\
\hline Endarachne bingamiae & J. Agardh \\
\hline Fucus spiralis & Linnaeus \\
\hline Halopteris filicina & (Grateloup) Kützing \\
\hline Hydroclathrus clathratus & (Bory) Howe \\
\hline Leathesia difformis & (Linnaeus) Areschoug \\
\hline Nemoderma tingitanum & Schousboe ex Bornet \\
\hline Padina pavonica & (Linnaeus) J.V. Lamouroux \\
\hline \multicolumn{2}{|l|}{ Sphacelaria sp. } \\
\hline Stypocaulon scoparium & Kützing \\
\hline \multicolumn{2}{|l|}{ Rhodophyta } \\
\hline \multicolumn{2}{|l|}{ Aglaothamnion sp. } \\
\hline \multicolumn{2}{|l|}{ Antithamnion sp. } \\
\hline Asparagopsis armata & Harvey \\
\hline $\begin{array}{l}\text { A. armata } \\
\text { (Falkenbergia rufolanosa phase) }\end{array}$ & (Harvey) F. Schmitz \\
\hline Caulacanthus ustulatus & (Turner) Kützing \\
\hline Centroceras clavulatum & (C. Agardh) Montagne \\
\hline Ceramium ciliatum & (Ellis) Ducluzeau \\
\hline Ceramium diaphanum & (Lightfoot) Roth \\
\hline Ceramium echionotum & J. Agardh \\
\hline Ceramium virgatum & Roth \\
\hline Corallina elongata & Ellis et Solander \\
\hline Chondracanthus acicularis & (Roth) Fredericq \\
\hline Chondracanthus teedei & (Mertens ex Roth) Kützing \\
\hline Chondria coerulescens & (J. Agardh) Falkenberg \\
\hline \multicolumn{2}{|l|}{ Calcareous crusts } \\
\hline \multicolumn{2}{|l|}{ Dasya sp. } \\
\hline Gastroclonium ovatum & (Hudson) Papenfuss \\
\hline Gastroclonium reflexum & (Chauvin) Kützing \\
\hline \multicolumn{2}{|l|}{ Gelidiella $\mathrm{sp}}$. \\
\hline Gelidium spinosum & (S. G. Gmelin) P. C. Silva \\
\hline Gelidium microdon & Kützing \\
\hline Gelidium pusillum & (Stackhouse) Le Jolis \\
\hline Grateloupia dichotoma & J. Agardh \\
\hline Gymnogongrus griffithsiae & (Turner) C.F. P.Martins \\
\hline Haliptilon virgatum & $\begin{array}{l}\text { (Zanardini) } \\
\text { Garbary et H. W. Johanson }\end{array}$ \\
\hline \multicolumn{2}{|l|}{ Herposiphonia sp. } \\
\hline \multicolumn{2}{|l|}{ Hildenbrandia sp. } \\
\hline Hypnea musciformis & (Wulfen) J.V. Lamouroux \\
\hline Jania capillacea & Harvey \\
\hline Jania rubens & (Linnaeus) J.V. Lamouroux \\
\hline \multicolumn{2}{|l|}{ Laurencia sp. } \\
\hline Laurencia viridis & Gil-Rodriguez and Haroun \\
\hline Lomentaria articulata & (Hudson) Lyngbye \\
\hline Lophosiphonia sp. & (Suhr) Kylin \\
\hline Nemalion helminthoides & (Velley) Batters \\
\hline
\end{tabular}

Table 1 (Contd.)

\begin{tabular}{ll}
\hline Taxa & Authorities \\
\hline $\begin{array}{l}\text { Osmundea pinnatifida } \\
\text { Peyssonnelia sp. } \\
\text { Phyllophora gelidioides }\end{array}$ & (Hudson) Stackhouse \\
$\begin{array}{l}\text { Plocamium cartilagineum } \\
\text { Polysiphonia denudata }\end{array}$ & $\begin{array}{l}\text { P.L. Crouan and } \\
\text { (Linnaeus) P. S. Dixon }\end{array}$ \\
$\begin{array}{l}\text { Polysiphonia tripinnata } \\
\text { Polysiphonia } \text { sp. }\end{array}$ & (Dillwyn) Greville ex Harvey \\
$\begin{array}{l}\text { Porphyra } \text { sp. } \\
\text { Pterocladiella capillacea }\end{array}$ & \\
$\begin{array}{l}\text { Pterosiphonia } \text { sp. } \\
\text { Rhodymenia holmesii }\end{array}$ & Santelices and Hommersand \\
$\begin{array}{l}\text { Schizymenia dubyi } \\
\text { Symphyocladia marchantoides } \\
\text { Tenarea tortuosa }\end{array}$ & $\begin{array}{l}\text { Ardissone } \\
\text { (Chauvin ex Duby) }\end{array}$ \\
(Harvey) Falkenberg \\
(Esper) M. Lemoine
\end{tabular}

This transformation reduces the differences between dominant and rare species, while keeping the importance of the more conspicuous ones that are crucial for posterior biotope classification procedures. Samples were grouped according to three factors - substratum type, exposure to wave action, and slope of the coast. According to Clarke and Warwick (2001) $R$-values obtained in ANOSIM tests range between -1 and 1 . A value of -1 would mean that similarities between samples across groups were higher than those within the groups (a rather awkward result), while a value of 1 would mean that all samples within groups are more similar to each other than to any samples from different groups. In general $R$-values fall between 0 and 1, indicating some discrimination between groups, and it is per se a useful comparative measure of the degree of separation of groups. All nmMDS analyses were based on the Bray-Curtis rank similarity matrix between samples (quadrats). The resulting plots used are two-dimensional displays of the sample configuration when attempting to satisfy all the conditions imposed by the rank similarity matrix. Associated stress values indicate the degree to which these conditions are satisfied. MVDISP was used to identify the physical factors that most contribute for sample variation. This was done by averaging all samples (quadrats) associated to each level of each factor in turn (shore height - three levels; substrate type - three levels; wave exposure - two levels; shore slope - four levels) into one data matrix, and performing an MDS analysis on the Bray-Curtis rank similarity matrix between factors (factor levels are considered instead of samples in the case of the MVDISP). To test for differences between and within identified groups of samples (quadrats) and their significance, the permutation procedure ANOSIM was applied to the similarity matrices referred earlier. SIMPER analysis was applied to the whole data matrix (square-root transformed) to identify the species contributing the most for the previously identified groupings, and associate them with the corresponding factor(s) level(s), and thus identify the biotopes. 


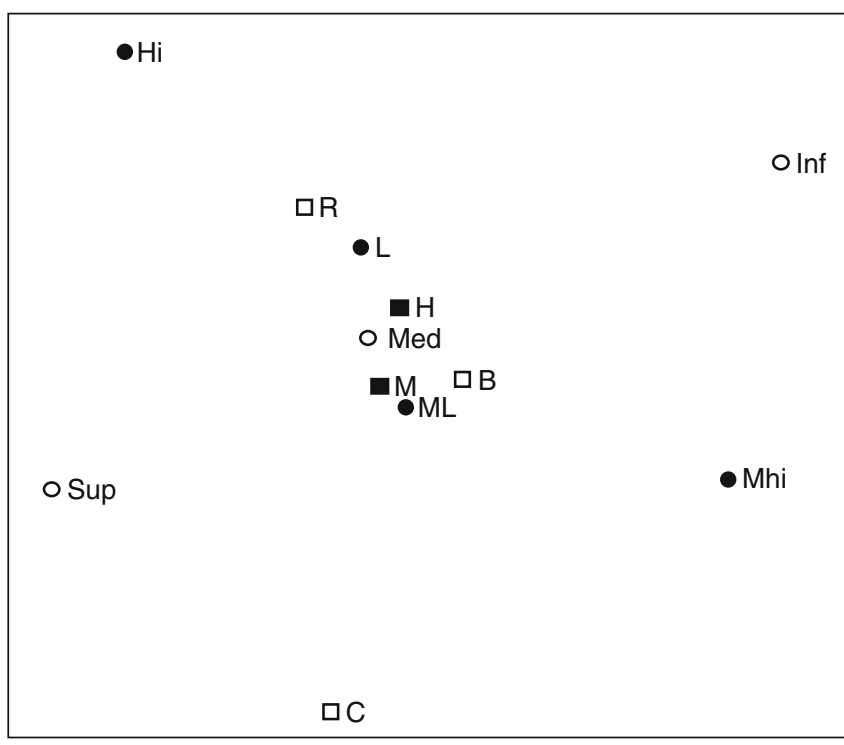

Fig. 2 nmMDS plot (stress 0.07) for samples averaged across all factor's levels (open circle - shore height: Inf-lower, Med-mid, Sup - upper; open square - substrate type: $B$ - boulders, $C-$ cobbles, $R$ - bedrock; solid square - wave exposure: $H$ - high; $M-$ medium; solid circle - shore slope: $L O$ - low, $M L$ - medium low, $M I$ - medium high, $H I$ - high). Factor dispersion values: shore height -1.333 ; substrate type -0.905 ; wave exposure -0.143 ; shore slope -1.024

\section{Results}

Seventy-four taxa were found during the present survey (Table 1).

Table 2 One-way ANOSIM results (global and pair-wise comparison between levels of each factor) for each of the factors considered (999 random possible permutations from a large number possible)

\begin{tabular}{lcc}
\hline Tests & $R$-value & Significance level (\%) \\
\hline Factor "shore height" & & \\
Global & 0.287 & $0.1^{*}$ \\
Lower vs medium & 0.17 & $0.1^{*}$ \\
Lower vs upper & 0.519 & $0.1^{*}$ \\
Medium vs upper & 0.167 & $0.1^{*}$ \\
Factor "substrate type" & & \\
Global & 0.069 & $0.1^{*}$ \\
Cobbles vs bedrock & 0.16 & $0.1^{*}$ \\
Cobbles vs.boulders & 0.069 & $0.2^{*}$ \\
Bedrock vs boulders & 0.039 & $0.2^{*}$ \\
Factor "wave exposure" & & \\
Global (= medium vs. high) & 0.021 & $0.3^{*}$ \\
Factor "shore slope" & & \\
Global & -0.013 & 88.1 \\
Medium low vs low & 0.008 & 19.8 \\
Medium low $v s$ medium high & -0.066 & 100 \\
Medium low vs high & -0.044 & 95 \\
Low vs medium high & 0.036 & 3.4 \\
Low vs high & -0.01 & 60.3 \\
Medium High vs High & 0.234 & 0.1
\end{tabular}

* Significance $<5 \%$
In the present study turf was divided into thick (calcareous or non-calcareous) and thin turfs, based on the DAFOR scale of its qualitative composition. The main constituents of thin turf were: Centroceras clavulatum, Ceramium spp., Ulva spp., Gastroclonium spp., Herposiphonia spp., Lophosiphonia spp., Polysiphonia denudata, Pterosiphonia spp., Sphacelaria spp. and Symphyocladia marchantioides. Calcareous thick turf is mainly composed of Corallina elongata, Jania rubens and Haliptilon virgatum; while non-calcareous thick turf is mainly composed of Caulacanthus ustulatus, Chondracanthus acicularis, Chondria coerulescens, Gelidiella sp., Gelidium spp., Gymnogongrus griffithsiae, Laurencia spp., Osmundea spp. and Stypocaulon scoparium.

\section{Quantitative approach}

The nmMDS showed that, among the factors studied, wave exposure was the one associated with less variation while all other factors have a balanced contribution to sample variation. This can be seen in Fig. 2, in which points represent the average of all samples associated with each level of the four factors. Points nearest to the centre imply less variability associated with the level of some factor.

Thus, the more disperse are the levels of one factor from the centre of the plot, the greater is the variability in the samples associated to that factor; it is thus assumed that the factor should be more important for the explanation of sample variability.

Table 3 Two-way crossed ANOSIM results (global and pair-wise comparison between levels of each factor) for factors substrate type and wave exposure at each of the shore height factor (999 random possible permutations from a large number possible)

\begin{tabular}{lcc}
\hline Tests & $R$-value & Significance level (\%) \\
\hline Upper & & \\
$\begin{array}{l}\text { Exposure global } \\
\text { (= medium vs. high) }\end{array}$ & -0.013 & 59.1 \\
Substrate global & 0.062 & $1.7^{*}$ \\
Cobbles vs bedrock & -0.027 & 63.1 \\
Cobbles vs boulders & 0.092 & 9.3 \\
Bedrock vs boulders & 0.045 & $3^{*}$ \\
Mid & & \\
Exposure global & 0.111 & $0.1^{*}$ \\
(= medium vs. high) & & \\
Substrate global & 0.245 & $0.1^{*}$ \\
Cobbles vs bedrock & 0.297 & $0.1^{*}$ \\
Cobbles vs boulders & 0.265 & $0.1^{*}$ \\
Bedrock vs boulders & 0.234 & $0.1^{*}$ \\
Lower & & \\
Exposure global & 0.049 & 6.5 \\
(= medium vs. high) & & \\
Substrate global & 0.255 & $0.1^{*}$ \\
Cobbles $v s$ bedrock & 0.786 & $0.1^{*}$ \\
Cobbles $v s$ boulders & 0.284 & $0.1^{*}$ \\
Bedrock $v s$ boulders & 0.137 & $0.1^{*}$ \\
\hline
\end{tabular}

* Significance $<5 \%$ 
Table 4 Upper littoral: taxa composition and average percentage abundance according to the association of taxa to substrate type

\begin{tabular}{|c|c|c|c|c|}
\hline & \multirow[t]{2}{*}{ Taxa } & \multicolumn{3}{|c|}{ Average abundance } \\
\hline & & Cobbles & Boulders & Bedrock \\
\hline \multirow[t]{6}{*}{ Taxa present in all three substrate categories } & Ulva spp. & 0.32 & 0.14 & 0.12 \\
\hline & Hildenbrandia sp. & 0.17 & 0.06 & 0.04 \\
\hline & Gelidium microdon & 0.13 & 0.15 & 0.14 \\
\hline & Codium adhaerens & 0.11 & 0.01 & 0.01 \\
\hline & Nemoderma tingitanum & 0.1 & 0.17 & 0.05 \\
\hline & Gelidium pusillum (thick turf) & 0.01 & 0.07 & 0.02 \\
\hline \multirow[t]{6}{*}{ Taxa present in only two substrate categories } & Corallina elongata & & 0.06 & 0.07 \\
\hline & Gymnogongrus griffithsiae (thick turf) & & 0.04 & 0.02 \\
\hline & Caulacanthus ustulatus (thick turf) & & 0.02 & 0.08 \\
\hline & Corallina elongata (calcareous turf) & & 0.01 & 0.06 \\
\hline & Fucus spiralis & & 0.01 & 0.1 \\
\hline & Laurencia sp. (thick turf) & & 0.01 & 0.04 \\
\hline \multirow[t]{14}{*}{ Taxa present in only one substrate category } & Gelidium pusillum (thick turf) & 0.01 & & \\
\hline & Pterosiphonia sp. (thin turf) & 0.04 & & \\
\hline & Gelidiella sp. (thin turf) & & 0.01 & \\
\hline & Grateloupia dichotoma & & 0.01 & \\
\hline & Gymnogongrus griffithsiae (thick turf) & & 0.03 & \\
\hline & Jania rubens (calcareous turf) & & 0.01 & \\
\hline & Polysiphonia denudata (thin turf) & & 0.01 & \\
\hline & Polysiphonia sp. (thin turf) & & 0.01 & \\
\hline & Stypocaulon scoparium (thick turf) & & 0.07 & \\
\hline & Cladophora sp. & & & 0.02 \\
\hline & Cystoseira abies-marina & & & 0.03 \\
\hline & Laurencia viridis (thick turf) & & & 0.07 \\
\hline & Nemalion helminthoides & & & 0.01 \\
\hline & Osmundea pinnatifida (thick turf) & & & 0.07 \\
\hline
\end{tabular}

The ecological categories used for biotopes in Fig. 3 are given in parentheses

Table 2 summarizes the ANOSIM tests performed to the square-root transformed data matrix considering separately the four factors plotted in Fig. 2, showing that shore height is the main factor causing variation (highest $R$-value that is significant), followed by substrate type and wave exposure (although the low $R$ values in these two latter cases), while shore slope does not significantly contribute to differences between samples ( $R$-value not significant). Differences in community composition between categories of all relevant factors (shore height, substratum and wave exposure) are also significant. Regarding shore height the medium level appears to be the transition between the lower and upper littoral ( $R$ - values of the same magnitude when compared with the latter two), while the upper and lower levels are most distant ( $R$-value is the highest of the pairwise comparisons). For substrate type, the levels that most differ are cobbles and bedrock (the highest $R$-value of the pair-wise comparisons), while boulders are equivalently different from both cobbles and bedrock ( $R$-values of the same magnitude), implying an intermediate position between cobbles and bedrock with regard to community composition.

Assuming shore height as the main separating factor of samples across the whole island, separate analyses were performed for each of the levels. Table 3 shows the two-way crossed ANOSIM results for the other two factors "substrate type" and "wave exposure" at each of these levels.
These results show that wave exposure is important only at the mid-littoral level and that there were significant differences between substrate types at all shore levels. However, at upper littoral the only striking difference was between bedrock and boulders.

Tables 4-6 summarize the information regarding the occurrence and relative abundance of algal taxa at the intertidal of the São Miguel island according to the SIMPER analysis based on the factor(s) responsible for significant differences: shore level, substratum type and exposure to wave action, respectively. No invertebrate taxa were representative enough to be picked out by the PRIMER analysis.

As a result of the previous analyses (Tables 4-6) and considering turf constituents and their classification adopted in the present study, 16 biotopes are proposed (Fig. 3).

This classification is based on the distinction observed between communities of stable and unstable substrata (bedrock and cobbles, respectively), boulders representing a transition between the other two substrate categories.

\section{Discussion}

The present study adds to our understanding of turf structure and constituents. Turfs are a prominent feature of intertidal communities in the Azores and have been 
Table 5 Mid-littoral: taxa composition and average percentage abundance according to the association of taxa to substrate type and wave exposure level

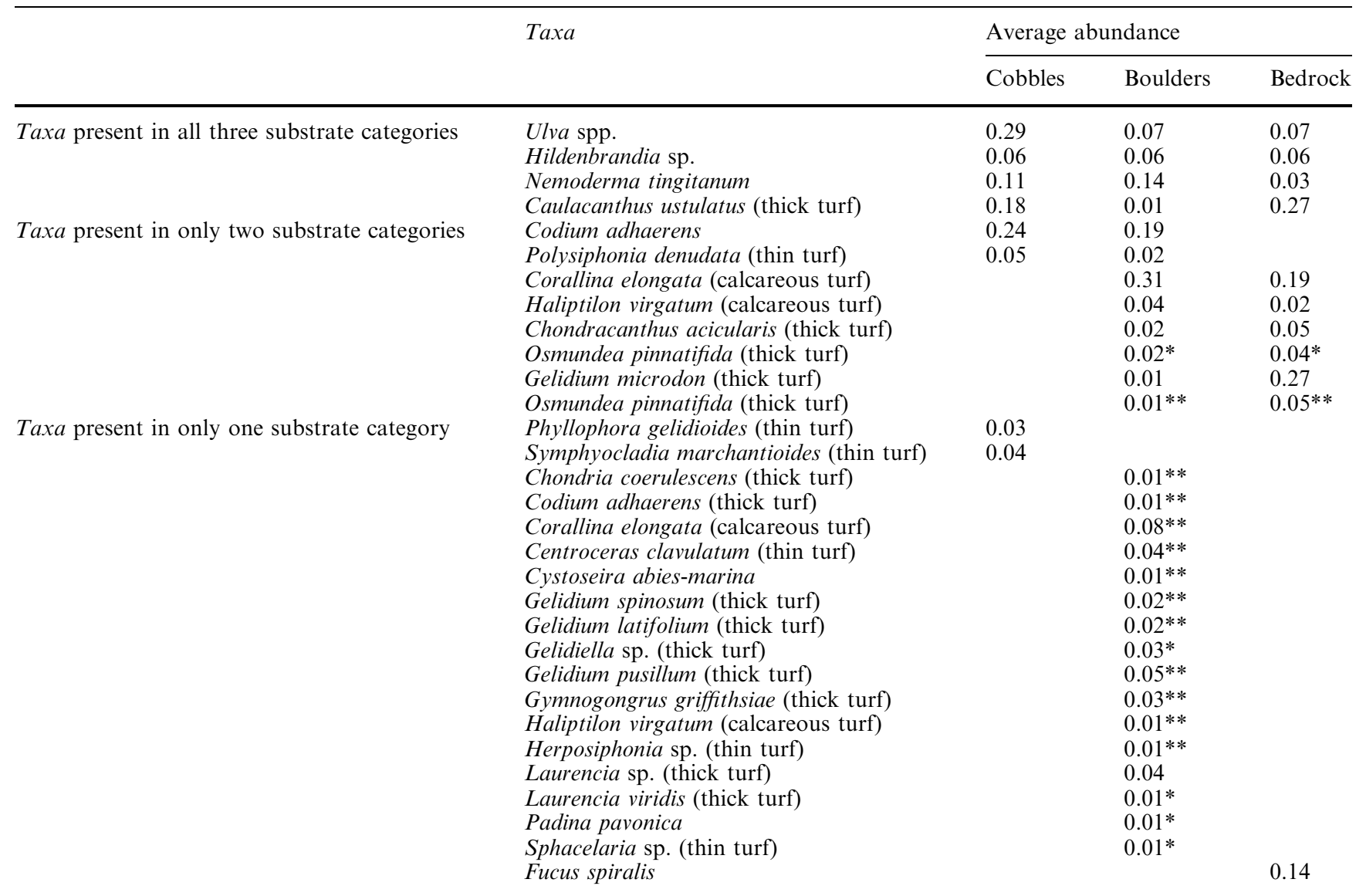

*Exclusive for high exposure; **Exclusive for medium exposure; the ecological categories used for biotopes in Fig. 3 are given in parentheses

described by many authors (e.g. Chapman 1955; Hawkins et al. 1990, 2000; Neto 1992; Bullock 1995; Neto and Tittley 1995; Tittley and Neto 2000). These turfs have been defined as growths of either diminute algae or diminute forms of larger species forming dense, compact stands rarely more than $2-3 \mathrm{~cm}$ high, with externally uniform appearance (Neto and Tittley 1995). The classification of turfs into three categories (thick calcareous and thick non-calcareous, and thin) and their qualitative characterisation builds upon previous classifications and should be further developed, focusing on a thorough quantitative characterization of the constituent species.

Considering the quantitative approach, shore level and substratum type are the factors that strongly influence community structure and those that also determine the major biotope separation. Exposure to wave action is a secondary factor in influencing community structure and composition as evidenced by the fact that it caused variation only at mid-eulittoral levels for the more stable substrata (cobbles and bedrock). This is partly due to the lack of sheltered habitats in the Azores due to the coastal morphology. The absence of invertebrate taxa in
Tables 4-6 reflects the low number of limpets and barnacles found in sampling quadrats at the low intertidal of São Miguel island. This is not surprising in the case of barnacles since the highest shore level at which sampling took place is at the lower limit of their distribution where density is low. Contrarily, the absence of limpets is the reflex of an anthropogenic impact. Limpets used to be abundant at the eulittoral level of Azorean shores, but have been overexploited (Martins et al. 1987) in all the islands and, despite protective measures, do not seem to be able to recover to their original levels (Hawkins et al. 1990). The species of algae that characterise the different intertidal shore levels in the present study (Tables 4-6) are consistent with the previous work on coastal communities in the Azores (Hawkins et al. 1990, 2000; Neto 1992, 1997, 2000a, 2000b; Morton et al. 1998; Tittley and Neto 1995, 2000). However, the referred studies consider bedrock as a representative of rocky substrata, ignoring boulder and cobble communities. The present study is the first to consider these substratum categories separately, and Tables 4-6 show the taxa that are common to more than one substratum 
Table 6 Lower littoral: taxa composition and average percentage abundance according to the association of taxa to substrate type

\begin{tabular}{|c|c|c|c|c|}
\hline & \multirow[t]{2}{*}{ Taxa } & \multicolumn{3}{|c|}{ Average abundance } \\
\hline & & Cobbles & Boulders & Bedrock \\
\hline \multirow[t]{7}{*}{ Taxa present in all three substrate categories } & Codium adhaerens & 0.33 & 0.22 & 0.01 \\
\hline & Ulva spp. & 0.18 & 0.01 & 0.01 \\
\hline & Corallina elongata (frondose) & 0.15 & 0.33 & 0.58 \\
\hline & Asparagopsis armata & 0.14 & 0.01 & 0.01 \\
\hline & Pterocladiella capillacea & 0.12 & 0.11 & 0.30 \\
\hline & Corallina elongata (calcareous turf) & 0.11 & 0.24 & 0.29 \\
\hline & Hildenbrandia sp. & 0.04 & 0.07 & 0.01 \\
\hline \multirow[t]{3}{*}{ Taxa present in only two substrate categories } & Cystoseira abies-marina & & 0.21 & 0.13 \\
\hline & Nemoderma tingitanum & & 0.04 & 0.01 \\
\hline & Caulacanthus ustulatus (thick turf) & & 0.01 & 0.06 \\
\hline \multirow[t]{16}{*}{ Taxa present in only one substrate category } & Caulacanthus ustulatus (thick turf) & 0.03 & & \\
\hline & Centroceras clavulatum (thin turf) & 0.05 & & \\
\hline & Gelidium pusillum (thick turf) & 0.04 & & \\
\hline & Herposiphonia sp. (thin turf) & 0.05 & & \\
\hline & Polysiphonia denudata (thin turf) & 0.06 & & \\
\hline & Antithamnion sp. (thin turf) & & 0.07 & \\
\hline & Chondracanthus acicularis (thick turf) & & 0.01 & \\
\hline & Gastroclonium reflexum (thick turf) & & 0.01 & \\
\hline & Haliptilon virgatum (calcareous turf) & & 0.01 & \\
\hline & Jania rubens (calcareous turf) & & 0.03 & \\
\hline & Padina pavonica & & 0.02 & \\
\hline & Stypocaulon scoparium (thick turf) & & 0.01 & \\
\hline & Stypocaulon scoparium (thick turf) & & 0.04 & \\
\hline & Symphyocladia marchantioides (thin turf) & & 0.01 & \\
\hline & Colpomenia sinuosa & & & 0.01 \\
\hline & Lomentaria articulata & & & 0.01 \\
\hline
\end{tabular}

The ecological categories used for biotopes in Fig. 3 are given in parentheses

category, as well as those that are exclusive to each category at each of the shore height levels. At the midshore level (Table 5), regarding taxa composition and relative abundance, separation also occurs within each substratum type according to the exposure level. This fact might be the result of higher influence of wave action at the intermediate level. Lower shore levels are largely immersed and thus less subject to wave action, while upper shore levels are protected from wave action due to wave energy dissipation at lower depths near the coast. Additionally, the method presented here implies that sampled quadrats at the mid-level (half distance between first alga and sea-water level) might vary a great deal in height, unless the shore slope is constant. A constant and smooth shore slope can be easily found at cobble bays, but very unlikely at boulder/bedrock headlands were steepness varies to a great deal. Thus, the resulting species composition and quantification is very variable. This is one of the characteristics of this level of the shore that causes difficulty in defining biotopes due to its patchiness and variability. However, if there is the intention to define methods to be implemented elsewhere, these should be well defined as is the case of the present manuscript. The resulting variability at the mentioned shore level will be consistent throughout the places where the methods are applied, and can thus be compared.

The results of the present study agree to a certain extent with Tittley and Neto's (2000) horizontal division of the eulittoral zone into upper, mid- and lower eulittoral that define major habitats, but not with their division according to wave exposure.

The broad similarity of communities across each shore level in four wave exposure categories of Tittley and Neto (2000) reflects the minor differences in wave exposure along the coast of this island. This was confirmed by the minor differences found in community structure caused by wave exposure in the present study. The differences between communities on very unstable cobble substrata and those associated with stable bedrock substrata, and the transitional nature of the intermediately stable boulder substratum evidence that stable and unstable substrata should be considered separately. It is very likely that boulder shores are mosaics of different successive stages with big boulders being more stable when compared with frequently disturbed smaller boulders/cobbles (Sousa 1979).

The biotope classification proposed in the present study considers shore height, substratum type and wave exposure and can be applied to the entire coast of São Miguel as it is based on data from study sites around the whole island. These show a distinction between the communities of stable and unstable substrata (bedrock and cobbles respectively), while those associated with boulders represent a transition between cobbles and bedrock due to the presence of common taxa.

The present work mainly intends to establish clear methods for the classification of communities and associated habitat characteristics, rather than being a phytosociological/phytocoenological work on coastal 


\section{SUBSTRATUM}

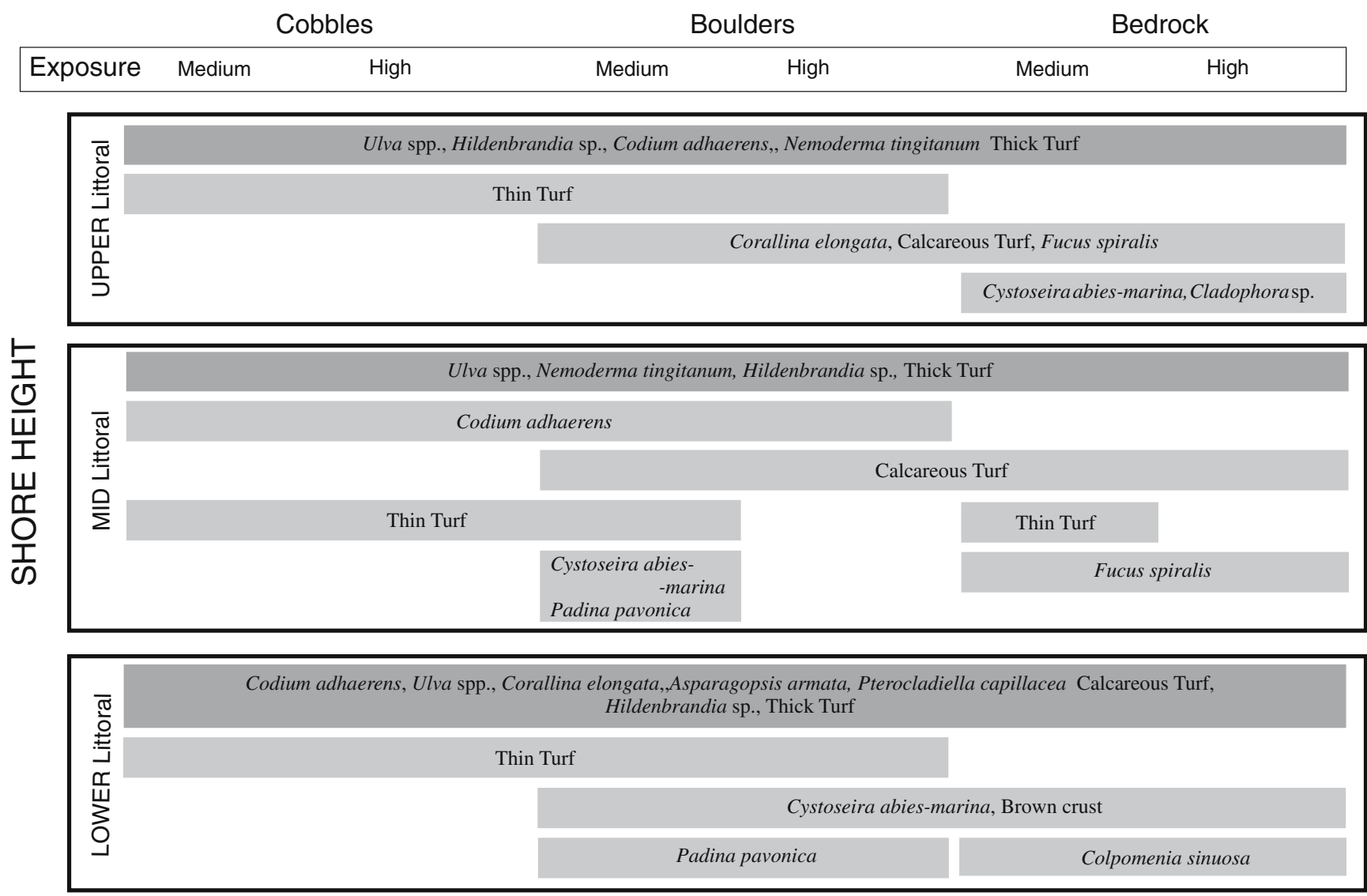

Fig. 3 Intertidal biotope proposal for the island of São Miguel

communities. Examples of such an approach are the comprehensive works of Braun-Blanquet (1928) for plant communities, den Hartog (1959) and den Hartog and Segal (1964) for water plant communities and of Connor et al. (1997, 2003) for coastal communities. However, these lack clarity in defining sampling procedures and require that samples are representative of some previously identified community. As such, samplers would be expected to have experience in coastal communities. Contrarily, the present study clearly defines how data should be colleted in the field and does not require experienced samplers. Additionally, through the use of computer software for data treatment, the present work improves on Braun-Blanquet's (1928) subjective tabular rearrangement procedures. There are clear benefits in a formal survey design being applied to the sampling procedures and the analysis of data. Repeatability of procedures is assured and thus spatial and/or temporal comparisons of results are possible. The work of Kent and Coker (1992) states that repeatability means objectivity in the sense that true objective comparison is only possible between studies that are developed in the exact same way. Rather than presenting another syntaxonomic approach, where communities/ biotopes are viewed as ecological taxonomic categories above the species level of taxonomy, that is the desired objectivity for future developments in biotope classification programmes.

Practical experience gained in the present study suggests that methods used in the field and subsequent data analysis should follow a more objective approach rather than descriptive. It is important to continue improving the method for biotope recording as it is at present incomplete. The next step is to extend its application to other geographical areas and implement seasonal variation studies to assess changes in biotopes. Further studies shall focus on sublittoral habitats and rock pools.

Turf communities often described as characteristic of Azorean coasts should be considered as a single ecological entity, representing a distinct biotope. These turf communities warrant future studies to focus on characterising them following methodologies yet to be defined and building on the work of Neto and Tittley (1995) who used quantitative analytical methods to identify differences in turf communities at littoral, shallow and deep sublittoral levels but without applying a community or biotope classification. Precisely defining the methods is important for comparisons between characterisation studies at different locations. It is with 
coastal management in mind that the present work proposes well-defined methods that are applicable to any location for biotope characterisation and monitoring. Comparisons of studies that use uniform methods will highlight differences and suggest mechanistic studies to explain the differences encountered.

Acknowledgements The authors wish to thank Dr. Kenneth Robert Clarke of the Plymouth Marine Laboratory, for helping with the data treatment and interpretation, Dr. I. Tittley of the Natural History Museum - London - for editing and revising this paper and for general discussions that contributed significantly to its completion, Dr. J.M.N. Azevedo, University of the Azores, for general discussions, and Ruben Couto and Patrícia Madeira for helping with field work. We also thank the anonymous referees who helped in improving the final version of this manuscript. This work was partially funded by CIRN-Centro de Investigação de Recursos Naturais, Fundação para a Ciência e a Tecnologia. The sampling procedures of the present study comply with the current laws of Portugal.

\section{References}

Augier H (1982) Inventory and classification of marine benthic biocenoses of the Mediterranean. Nature and Environment Series 25. Council of Europe, Strasburg

Braun-Blanquet J (1928) Pflanzensoziologie. Grundzüge der Vegetationskunde. Springer-Verlag, Berlin Heidelberg New York

Brito RS (1955) A Ilha de São Miguel. Estudo Geográfico. Instituto de Alta Cultura, Centro de Estudos Geográficos, Lisboa

Bullock RC (1995) The distribution of the molluscan fauna associated with the intertidal coralline algal turf of a partially submerged volcanic crater, the Ilhéu de Vila franca, São Miguel, Azores. In: Martins AMF (ed) Proceedings of the Second International Workshop of Malacology and Marine Biology of Vila Franca do Campo, São Miguel, Azores. Açoreana 4(suppl):9-55

Cerame-Vivas MJ, Gray IE (1966) The distribution pattern of benthic invertebrates of the continental shelf of North America. Ecology 47:260-270

Chapman G (1955) Aspects of the fauna and flora of the Azores. VI. The density of animal life in the coralline algae zone. Annals and Magazine of Natural History, series 12:398-400

Clarke KR, Warwick RM (2001) Change in marine communities: an approach to statistical analysis and interpretation, 2nd edn. PRIMER-E, Plymouth

Connor D, Brazier DP, Hill TO, Northen KO (1997) Marine Nature Conservation Review: marine biotope classification for Britain and Ireland, vol 1, Littoral biotopes, Version 97.06. JNCC Report, no. 229

Connor DW, Allen JH, Golding N, Lieberknecht LM, Northen KO, Reker JB (2003) The national marine habitat classification for Britain and Ireland, Version 03.02. JNCC, Peterborough, http://www.jncc.gov.uk/marinehabitatclassification (4 November 4 2003)

Dauvin JC (1995) The development of the marine ZNIEFF (Zones Naturelles d'Interêt Ecologique, Faunistique et Floristique) in France. In: Hiscock K (ed) Proceedings of a BioMar-Life workshop held in Cambridge, 16-18 November 1994. Classification of Benthic Marine Biotopes of the North East Atlantic. Joint Nature Conservation Committee, pp47-53

Dauvin JC, Bellan G, Bellan-Santini D, Gastric A, Comolet-Tirman J, Francour P, Gentil F, Girard A, Gofas S, Mahe C, Noel P, Reviers B (1994) Typologie des ZNIEFF-Mer. Liste des parameters et des biocenoses des cotes françaises metropolitaines. Secretariat Faune-Flore Museum National d'Histoire Naturelle, Collection patrimoines naturels, vol 12

den Hartog C (1959) The epilithic algal communities occurring along the coast of the Netherlands. Wentia 1:1-241 den Hartog C, Segal S (1964) A new classification of the waterplant communities. Acta Bot Neerl 13:367-393

Foster MS, Nigg EW, Kiguchi LM, Hardin DD, Pearse JS (2003) Temporal variation and succession in an algal-dominated high intertidal assemblage. J Exp Mar Biol Ecol 289:15-39

Hawkins SJ, Jones HD (1992) Marine Field Course Guide. 1. Rocky Shores. Marine Conservation Society. Immel Pub., London

Hawkins SJ, Burnay LP, Neto AI, Cunha RT, Martins AMF (1990) A description of the zonation patterns of molluses and other important biota on the south coast of São Miguel, Azores. Açoreana (suppl):21-38

Hawkins SJ, Corte-Real HBSM, Pannacciulli FG, Weber LC, Bishop JDD (2000) Thoughts on ecology and evolution of the intertidal biota of the Azores and other Atlantic islands. Hydrobiologia 440:3-17

Hiscock K (ed) (1995) Classification of benthic marine biotopes of the north-east Atlantic. Proceedings of a BioMar-Life workshop held in Cambridge, 16-18 November 1994. Peterborough, Joint Nature Conservation Committee

Instituto Hidrográfico (1981) Roteiro do Arquipélago dos Açores. PUB. (N) -IH-128-SN, Lisboa

Kent M, Coker P (1992) Vegetation description and analysis. A practical approach. John Wiley and Sons, Chichester

Larkum AW (1960) Botany (Algae). Azores expedition 1959, Final Report. The Exploration Board, Imperial College of Science and Technology, London, pp 120-127

Lawson GW, John DM (1982) The marine algae and coastal environment of tropical West Africa. Nova Hedwigia 70. J. Cramer, Vaduz

Lawson GW, Norton TA (1971) Some observations on the littoral and sublittoral zonation of Teneriffe (Canary Isles). Bot Mar 14:116-120

Leeder MR (1982) Sedimentology - process and product. Chapman and Hall, London

Macedo FLWFM (2002) Biótopos do intertidal rochoso da ilha de São Miguel (Açores). Relatório de estágio para conclusão da Licenciatura em Biologia - Ramo de Biologia Marinha. Universidade dos Açores, Ponta Delgada

Martins HR, Santos RS, Hawkins SJ (1987) Exploitation of limpets (Patella spp.) in the Azores with a preliminary analysis of the stocks. Report to ICES Shellfish Committee

Morton B, Britton JC, Martins AMF (1998) Coastal ecology of the Azores. Sociedade Afonso Chaves, Ponta Delgada

Mumby PJ, Harborne AR (1999) Development of a systematic classification scheme of marine habitats to facilitate regional management and mapping of Caribbean coral reefs. Biol Cons $88: 155-163$

Neto AI (1991) Zonação litoral de dois locais da ilha de São Miguel (Açores) e estudo dos seus povoamentos fitobentónicos, iv +116p. Trabalho de síntese, Provas de Aptidão Pedagógica e Capacidade Científica. Universidade dos Açores, Ponta Delgada

Neto AI (1992) Contribution to the taxonomy and ecology of the Azorean benthic marine algae. Biol J Linn Soc 46:163-176

Neto AI (1997) Studies on algal communities of São Miguel, Azores. PhD Thesis. Universidade dos Açores, Ponta Delgada

Neto AI (2000a) Observations on the Biology and Ecology of Selected Macroalgae from the Littoral of São Miguel (Azores). Bot Mar 43:483-498

Neto AI (2000b) Ecology and dynamics of two intertidal algal communities on the littoral of the island of São Miguel (Azores). Hydrobiologia 432:135-147

Neto AI (2001) Macroalgal species diversity and biomass of subtidal communities of São Miguel (Azores). Helgol Mar Res 55:101-111

Neto AI, Tittley I (1995) Structure and Zonation of algal turf communities on the Azores: a numerical approach. Boletim do Museu Municipal do Funchal 4(suppl):487-504

Oliveira EC, Mayral EM (1976) Seasonal distribution of intertidal organisms at Ubatuba, São Paulo (Brasil). Revista Brasileira de Biologia 36:305-316 
Otero-Schmitt J (1993) Some local patterns of zonation of benthic marine flora and fauna in Sal, Santiago, S. Vicente and Brava (Cape Verde Islands). Courier Forschungs-Institut Senckenberg 159:45-52

Pérès JM, Picard J (1964) Nouveau manuel de bionomie benthique de la Mer Mediterranée. Recueill des Travaux de la Station Marine d'Endôume 31:1-138

Picton BE, Costello MJ (eds) (1997) BioMar biotope viewer: a guide to marine habitats, fauna and flora of Britain and Ireland. Environmental Sciences Unit, Trinity College, Dublin

Price JR, Scott FJ (1992) The turf algal flora of the Great Barrier Reef. Part I. Rhodophyta. James Cook University, Townsville

Pryor J (1967) Intertidal marine algae of São Jorge. Chelsea College Azores Expedition (July-October 1965) Final Report. Chelsea College, London, pp 17-30

Ricardo RP, Madeira MAV, Medina JMB, Marques MM, Furtado AFAS (1977) Esboço pedológico da ilha de São Miguel (Açores). Anais do Instituto Superior de Agronomia 37:275-385

Rogers CS, Salesky NH (1981) Productivity of Acropora palmata (Lammarck), macroscopic algae, and algal turf from Tague Bay reef, St. Croix, US Virgin Islands. J Exp Mar Biol Ecol 49:179187

Russell G (1991) Vertical Distribution. In: Mathieson AC, Nienhuis PH (eds) Ecosystems of the World 24. Intertidal and Littoral Ecosystems. Elsevier, Amsterdam, pp 43-65

Santelices B, Abbot IA (1978) New record of marine algae from Chile and their effect on phytogeography. Phycologia 17:213222
Sousa WP (1979) Disturbance in marine intertidal boulder fields: the non-equilibrium maintenance of species diversity. Ecology 60:1225-1239

Southward AJ, Orton JH (1954) The effects of wave-action on the distribution and numbers of the comonner plants and animals living on the Plymouth breakwater. J Mar Biol Ass UK 33:1-19

Stewart JG (1982) Anchor species and epiphytes in intertidal algal turf. Pacific Science 36:45-59

Stewart JG (1989) Establisment, persistent and dominance of Corallina (Rhodophyta) in algal turf. J Phyc 25:436-446

Thomas MLH (1986) A physically derived exposure index for marine shorelines. Ophelia 25:1-13

Tittley I, Neto AI (1995) The marine algal flora of the Azores and its biogeographical affinities. Boletim do Museu Municipal do Funchal 4(suppl):747-766

Tittley I, Neto AI (2000) A provisional classification of algalcharacterised rocky shore biotopes in the Azores. Hydrobiologia 440:19-25

Tittley I, Neto AI, Farnham WF (1998) Marine algae of Flores. Azores: ecology and floristics. Boletim do Museu Municipal do Funchal 5(suppl):463-479

Zacharias MA, Roff JC (2000) A hierarquical ecological approach to conserving marine biodiversity. Conserv Biol 14:1327-1334

Zacharias MA, Roff JC (2001) Explanations of patterns of intertidal diversity at regional scales. J Biogeog 28:471-483

Zacharias MA, Morris MC, Howes DE (1999) Large scale characterisation of intertidal communities using a predictive model. J Exp Mar Biol Ecol 239:223-242 